\title{
Die opstanding in die Jodedom, die Grieks-Romeinse wêreld en die Nuwe Testament
}

\author{
Ernest van Eck (Oos-Moot) ${ }^{1}$ \\ Navorsingsassosiaat: Departement Nuwe-Testamentiese Wetenskap \\ Universiteit van Pretoria
}

\begin{abstract}
Resurrection in Judaism, the Greek-Roman world and the New Testament

The article shows that in the Jewish and Greco-Roman worlds' belief in the afterlife underwent a progressive development. It focuses on a "belief" in no life after death in pre-exilic Judaism, which developed into the belief that the dead did not cease to exist in the afterlife. This view again developed into a belief that the dead still lived, but only as a shadow of the living existence. In post-exilic Judaism the belief in a general eschatological resurrection was held, a conviction that was the result of the understanding of martyrdom in especially the Maccabean period. In the Greco-Roman world the conviction initially was that there was no life after death (Homer), and later a belief in the immortality of the soul (Plato) set in. The mystery cults also upheld a belief in the resurrection of the dead. Interpreted from a Jewish perspective on afterlife in the New Testament, the resurrection of Jesus was seen as an individual resurrection before the general eschatological resurrection that inaugurates "the age to come".
\end{abstract}

\section{INLEIDENDE OPMERKINGS}

Die doel van die onderhawige bydrae is om vanuit 'n bepaalde hoek aan die huidige debat oor die opstanding van Jesus Christus deel te neem. Die bydrae bestaan uit twee artikels. In die onderhawige artikel word aan twee sake aandag gegee. Eerstens word 'n kort beskrywing aangebied van die verwagtings wat geheers het ten opsigte van lewe na die dood in die Joodse en Grieks-Romeinse wêrelde, waarna aandag gegee word aan die "saak" wat die Nuwe Testament ten opsigte van die opstanding van Jesus aan die orde

\footnotetext{
${ }^{1}$ Dr Ernest van Eck (MA, DD) is as navorsingsassosiaat betrokke by prof dr Andries G van Aarde se navorsingsprojek "Bybelse Teologie en Hermeneutiek," Departement NuweTestamentiese Wetenskap, Fakulteit Teologie, Universiteit van Pretoria.
} 
wil stel. In 'n tweede artikel word aandag gegee aan die standpunte van drie prominente deelnemers aan die huidige debat oor die opstanding, te wete William Lane Craig, Gerd Lüdemann en John Dominic Crossan. Vervolgens word die standpunte oor die opstanding van die genoemde Nuwe-

Testamentici gebruik as vertrekpunt om twee sake wat van belang is in die ondersoek na die opstanding van Jesus aan die orde te stel: die verhouding tussen vooronderstellings en resultate (in die ondersoek na die opstanding van Jesus Christus), en die aard van die tekste van die Nuwe Testament as geskiedenis en teologie. Ten slotte word 'n eie verstaan van die opstanding, en na-opstanding verskynings van Jesus aangebied.

\section{LEWE NA DIE DOOD EN OPSTANDING IN PALESTINA IN DIE EERSTE EEU}

\subsection{Lewe na die dood in die Jodedom}

Vroeg-Israelitiese (pre-eksiliese) spekulasie oor lewe na die dood vind ons in 2 Samuel 14:14: "Ons sal almal sterf en soos water wees wat op die grond uitgegooi is en nie weer bymekaargemaak kan word nie". "Lewe" na die dood was niks meer as ' $n$ soort van bestaan in Hades $/$ Sheol ${ }^{2}$ onder die aarde nie. Dit was 'n lewe van stilte, 'n lewe waarin daar geen kontak meer was met Jahwe of die kultus nie (vgl Ps 6:5; 16:10; 30:9; 39:13; 49:15; 88:3-10; 115:17; 146:4; Gen 3:9; Job 3:13-19; 7:9-10; 14:10-15, 21; 19:25-27; Pred 2:14-16; $3: 20 ; 9: 4-5$; Jes $38: 10-18)$. Sheol is gesien as "a wilderness: a place of dust to which creatures made of dust have returned. Those who have gone there are 'the dead', they are 'shades ... and they are asleep'" (Wright 2003:89).

Verskeie apokriewe geskrifte skets dieselfde prentjie, te wete dat daar geen lewe na die dood was nie (kyk o a Tobit 1:17-18; 3:6; Sirag 14:17-18; 17:28; 38:20-23; 41:1-4, die Wysheid van Salomo 6:17-20). Bestaan in die onderwêreld was 'n nie-bestaan ${ }^{3}$. Die enigste "lewe na die dood" was, volgens Sirag (30:4-6; 44:13-14), die nalaat van 'n eerbare naam (wat nooit vergeet sal word nie), en kinders (veral seuns; kyk Riley 1995:10-13; Segal 1997:96; Craffert 1999:46; Wright 2003:99-100). Die graf was die einde van enige vrugbare lewe (Segal 1997:91; Porter 1999:57; Craffert 1999:45) ${ }^{4}$. Hierdie beskouing van lewe en dood het hand en hand gegaan met die pre-eksiliese

\footnotetext{
${ }^{2}$ Vir 'n beskrywing van Sheol/Hades, asook die ontwikkeling van die begrippe Sheol/Hades, Gehenna en "hel", kyk Craffert (1999:71-83). Job 10:21-22 beskryf die plek waarheen die afgestorwenes (Sheol) gaan soos volg: "[V]oor dat ek weggaan na die stikdonker land toe en nooit terugkeer nie, na die land van die donker nag met sy diep duisternis waar niks georden is nie, waar die lig self donker is."

3 "The dead had no further relationship with Yahweh" (Eichrodt 1967:221). "To be sure, YHWH rules Sheol, yet there is no relation between him and the dead" (Kaufmann 1960:314).

${ }^{4}$ Die dood was die aanvaarbare einde van iemand wat 'n vrugbare lewe gelei het (Kaplan 1988:16). 'n Voortydige dood egter, was gesien as 'n onvoltooide lewe, en rede vir smart (Kaplan 1988:16; vgl Pred 7:17; Jes 38:10).
} 
verstaan van God: God was die God van die lewendes, en nie die God van die dooies nie (Kaplan 1988:8). Of, soos Wright (2003: 93) dit stel: "[H]ope lived on within the covenant and promise of YHWH."

Die toestand van die dooies in Sheol was egter nie beskou as 'n toestand van totale nie-bestaan nie ${ }^{5}$ (vgl Job 14:22). Soos in Mesopotamië en Kanaän, het ook Israel die "kultus van die dooies" beoefen. Hierdie kultus het bestaan uit vrees vir die afgestorwenes, die handhaaf en uitvoering van korrekte begrafnisrites en gebruike (sodat die afgestorwene bv Sheol kon bereik; kyk Kaplan 1988:14), versorging van die afgestorwenes (bv die plaas van voedsel en water by afgestorwenes - selfs in grafte), kultiese geleenthede ter ere van afgestorwenes, "necromancy" (kommunikasie met die "siele" van afgestorwenes) ${ }^{6}$ en gebede vir afgestorwenes ${ }^{7}$. Die handhawing van hierdie kultus dui daarop dat reeds baie vroeg daar geglo is in 'n "soort" lewe na die dood (Riley 1995:14; Craffert 1999:46). Die afgestorwenes - al was hulle dood - kon eet, drink, met lewendes kommunikeer en selfs verskyn aan die wat nog lewe ${ }^{8}$ (Kaplan 1988:15-16; Segal 1997:92; Craffert 19999).

Aansluitend by die oortuiging dat die toestand van die dooies in Sheol nie 'n toestand van totale nie-bestaan was nie, oordeel Jacob (1958:304; kyk ook Kaplan 1988:15) dat tekste soos Jesaja 14:8-20 en Esegiël 32:17-32 daarop dui dat die oortuiging bestaan het dat Sheol uit verskillende "plekke" bestaan het. Die koning van Babel (wat die Israeliete verdruk het) eindig nie net in die doderyk nie, maar in sy "diepste deel" (Jes 14:15), en die faroa (die koning) van Egipte eindig by die "eerloses" (Eseg 32:19), terwyl die ander konings en leiers van die aarde op hulle trone in die doderyk sit (vgl Jes $14: 9)^{10}$.

\footnotetext{
5 "At the moment of death the body does not disintegrate ... but for a certain length of time continues to retain the features of the living being. The individual dies but does not cease to exist, yet this existence is only a shadow of the living existence" (Jacob 1958:301).

${ }^{6}$ In hierdie verband kan die volgende opmerking van Kaplan (1988:16) vermeld word: "Official Judaism, however, condemned the practice of necromancy and never were the dead considered to enjoy superior knowledge." Die rede hiervoor word deur Craffert (1999:34-35) soos volg beskryf: "The establishment of the kingdom and the centralisation of the cult under king David and his son Solomon created a whole new religious setting in Israel. In order to establish the temple cult as a national cult, it was necessary to exclude all alternative ways of divine interaction. If the clan unity in earlier times was guaranteed by the tombs of the ancestors and the ancestral altar, the national temple which replaced the local altars had no room for dead ancestors."

${ }^{7} \mathrm{Vgl}$ in hierdie verband die opdrag van Tobit aan sy seun voor hy sterf: "Pour out your bread upon the grave of the righteous and do not give it to sinners" (Tobit 4:27, in Riley 1995:14).

${ }^{8} \mathrm{Vgl}$ in hierdie verband Samuel se verskyning aan Saul in 1 Samuel 28:11-19.

${ }^{9}$ Vir 'n goeie oorsig oor graftipes, begrafnisrites en die funksies wat die dooies onder die lewendes vervul het in die vroeg-Israelitiese, tweede tempel en Romeine tydperke, kyk Craffert (1999:1-41, 62-69).

${ }^{10}$ Volgens Wolf (1985:115) dui Jesaja 14 en Esegiël 32 ook op die gevolg as iemand nie 'n eervolle begrafnis gehad het nie.
} 


\section{Die opstanding in die Jodedom}

In die tweede eeu voor Christus (in die na-eksiliese Jodedom) vind 'n verdere ontwikkeling plaas wat die Joodse beskouing van lewe na die dood en opstanding betref, te wete die hoop op 'n opstanding na die dood. Die hoop op 'n opstanding kan, volgens Kaplan (1988:1-17), duidelik afgelei word uit tekste soos Jesaja 66:20 en Jesaja 25:8 wat klem lê op die alomteenwoordigheid van God. Geloof in die alomteenwoordigheid van God het beteken dat Sheol nie buite die magsveld of beheer van God kon lê nie. God sou daarom nooit van die dooies vergeet nie ${ }^{11}$.

Hierdie verstaan van God se alomteenwoordigheid ${ }^{12}$ gee uitdrukking aan 'n post-eksiliese Joodse eskatologie wat ('n gemeenskaplike) opstanding na die dood insluit. Die ter sake tekste in hierdie verband is Esegiël $37^{13}$, Hosea 13:14, Jesaja 26:19, en in besonder Daniël 12:2 ${ }^{14}$. Ook 2 Makkabeërs

\footnotetext{
${ }^{11}$ Vergelyk Jesaja 25:8 in hierdie verband: "Hier sal die Here God die dood vir ewig vernietig, en die trane op almal se gesigte afvee."

${ }^{12}$ Wright is van oordeel dat meer as net die oortuiging dat God alomteenwoordig is gesien kan word as die grond vir die hoop in die post-eksiliese Jodedom dat daar 'n opstanding na die dood sal wees. "The vision of YHWH's creation and covenant; his promises and faithfulness to them; his purposes for Israel, not at least his gift of the land; his power over all opposing forces, including finally death itself; his love for the world, for his human creatures, for Israel in particular, and especially for those who served and followed him and followed his way; his justice because of which evil would eventually be condemned and righteousness upheld - this vision of the creator and covenant god underlies the ancient belief in the national and territorial hope ... and the eventual belief that YHWH would raise the dead" (Wright 2003:127).
}

${ }^{13}$ Die profesie in Esegiël 37 kan op een van twee wyses geïnterpreteer word. Eerstens kan die inhoudelike daarvan verwys na die feit dat God Israel uit ballingskap sal bevry en hulle weer nuwe lewe in hulle eie land sal gee, of dit kan verwys na 'n algemene opstanding na die dood. Hasel (1980:265-270) se bespreking van Esegiël 37 in terme van Joodse apokaliptiese tekste soos Hosea 6:1-3; 14:4-7, Daniël 12:2 en Jesaja 26:19 ('n bespreking waarin hy ook aandag gee aan die Wirkungsgeschichte van hierdie gedeelte), toon myns insiens oortuigend aan dat ons hier met 'n verwagting in 'n algemene opstanding te make het ( $\mathrm{vgl}$ ook Jacob 1958:310; Kaplan 1988:21-25).

\footnotetext{
14 "Baie van dié wat ontslaap het, sal uit die graf opstaan, party tot die ewige lewe en party tot ewige skande en veragting" (Dan 12:2). Daniël 12:2 is heel waarskynlik 'n uitbouing van Jesaja 26:19 ('n visioen dat die volk weer sal opstaan uit hulle sonde en God sal dien), wat uitdrukking gee aan die oortuiging van 'n algemene opstanding. Day (1996:244-250), op sy beurt weer, is van mening dat Jesaja 26:19 'n uitbouing van Hosea 13:14 is. Segal (1997:97) maak oor Daniël 12:2 die volgende opmerking: "This particular passage, the earliest undoubted reference to resurrection in the Hebrew Bible, suggests that both the righteous and the very evil need to be resurrected for the purpose of giving them their well-deserved rewards. This hope no doubt comes from the observation that some good have been suffering" (sy beklemtoning; kyk ook Wright 2003:109). Volgens Kaplan (1988:18) kan die oortuiging soos uitgedruk in Daniël 12:2 ook gevind word in Psalm 16:10-11, Psalm 49:14-15 en Psalm 22, 73 en 78. "These authors, confronted by the problem of theodicy, turn to the possibility of a continuing fellowship with God beyond the boundaries of this life" (Russell 1964:356). Kaplan is verder van oordeel dat in die laasgenoemde Psalms daar miskien ook sprake is van "stirrings of the idea of individual resurrection" (Kaplan 1988:19). Sy koppel hierdie moontlikheid aan 1 Konings 17:17, 2 Konings 4:34 en 2 Konings 13:21 waarin respektiewelik God 'n weduwee se seun deur Elia opwek, 'n kind deur Elisa weer laat lewe en 'n man weer lewe wanneer hy deur Elisa aangeraak word. Of hier wel sprake is van die hoop op ' $n$ individule opstanding, is egter te bevraagteken.
} 
7:9 gee uitdrukking aan dieselfde verwagting, met dieselfde kwalifikasie, te wete dat alleen die regverdiges deel sal kry aan hierdie opstanding. 2 Makkabeërs 7:36, 12:39-45 en 14:46, die Testament van die Twaalf Patriarge (TZeb 10:2) en die Psalms van Salomo 3:10-12 gee ook uitdrukking aan die oortuiging dat daar aan die einde van die tyd 'n algemene opstanding sal wees: die regverdiges sal lewe ${ }^{15}$ en die goddeloses sal vir ewig tot Sheol verdoem word (kyk Riley 1995:16-17; Porter 1999:59-61) ${ }^{16}$.

Verskeie gedeeltes in Joodse inter-testamentêre literatuur ondersteun bogenoemde gedagte wat in Daniël 12:2 en 2 Makkabeërs na vore kom. 1 Henog 1-36, byvoorbeeld, beskryf duidelik hoe die oordeel sal plaasvind om te bepaal wie regverdig en wie goddeloos geleef het, en 4 Esra 7:28-35, die Testament van Juda 25:1-4, die Testament van Sebulon 10:1, die Testament van Moses 10:8-10, die Apokalips van Moses, die Testament van Benjamin 10:6-11, SibOr 4:179-192, die Psalms van Salomo 3:11 en 2 Barug 49-52 ${ }^{17}$ adem dieselfde oortuiging: wanneer God eendag die aarde herskep, sal die

\footnotetext{
${ }^{15}$ Afgesien van die feit dat die regverdiges sal lewe en die goddeloses vir ewig verdoem sal word, het diegene wat 'n ander wysheid geleer het, 'n spesiale beloning ontvang: hulle sal soos sterre in die hemel skyn. Hierdie beskouing vind heel waarskynlik sy wortels in die baie vroeë oortuiging dat sterre engele is wat lig uitstraal (vgl Rig 5:29; Job 38:7).
}

${ }^{16}$ Crossan (2003:34-45) interpreteer Daniël 12:2, Jesaja 26:19 en die tekste in 2 Makkabeërs soos volg: Daniël 12:2 verwys beslis na opstanding uit die dood en dus na lewe na die dood. Daniël 12:2 visualiseer egter nie 'n algemene opstanding nie, maar 'n opstanding van die regverdiges en martelare. Aangesien Daniël 12:2 Jesaja 26:19 letterlik opneem, verwys Daniël 12:2 heel waarskynlik na 'n liggaamlike opstanding. Laasgenoemde interpretasie van Daniël 12:2 word in 2 Makkabeërs bevestig waar daar telkens na 'n liggaamlike opstanding verwys word. Verder: indien 2 Makkabeërs (circa 100 vC) en 4 Makkabeërs (circa 40 nC) met mekaar vergelyk word, is die gedagte van lewe na die dood (en spesifiek 'n liggaamlike opstanding) in hierdie tekste nie die gevolg van 'n filosofiese verstaan van die mens se eindbestemming nie, maar ' $n$ teologiese visie in terme van die regverdiging van die martelare wie se liggame geskend was tydens hulle marteling. Omdat die martelare se liggame gemartel en verwoes is, sal die regverdige God, om hulle in ere te herstel, hulle liggaamlik laat opstaan. Hierdie standpunt van Crossan vind ondersteuning in werke (so vroeg as die) van Jacob (1958:315) en Gowen (1986:92). Volgens laasgenoemde kon die tradisionele (Deuteronomistiese) Ou-Testamentiese eskatologie nie 'n antwoord bied op die vraag na die regverdigheid van die sterf van martelare in die tweede eeu voor Christus nie. Godsdienstige vervolging het ' $n$ nuwe eskatologie vereis, te wete 'n algemene opstanding waartydens die martelare beloon sal word. Jacob (1958:314) stem hiermee saam: "It was Renan who concluded that the martyr was the creator of the belief in the second life" (vgl ook Segal 1997:99-100; Craffert 1999:49 en Wright 2003:113-115 wat dieselfde standpunt huldig). Ringgren (1966:244-247) weer, oordeel dat die verwysings na die opstanding in die tekste deur Crossan genoem (as verwysend na 'n eskatologiese, algemene opstanding), verstaan moet word teen die agtergrond van drie moontlike antesedente: die Kanaänitiese idee van die vrugbaarheidsgod wat sterf en opstaan, die oortuiging dat God sterker is as die dood en Sheol, en moontlike Persiese invloede. Vir die standpunte van Hengel, Widengren, Pearson, Barret en Hinnells in hierdie verband, kyk Riley (1995:15, voetnoot 24). Eenstemmigheid bestaan dus nie in terme van die interpretasie van Daniël 12:2 en Jesaja 26:19 nie.

${ }^{17}$ Vir 'n meer volledige bespreking van hierdie en ander tekste, kyk Kaplan (1988:37-58). 


\section{Die opstanding in die Jodedom}

regverdiges opstaan ${ }^{18}$. Meer spesifiek handel 2 Makkabeërs 7:14 oor die lyding van die martelare onder Antiogus Epifanus en die belofte van beloning in 'n nuwe lewe. 2 Barug 49-52 beskryf hoe die opstandingsliggaam sal lyk (kyk Charlesworth 1983:xxxiii) en 4 Makkabeërs 18:16-19 bevat die belofte van 'n opstanding op grond van God se alomteenwoordigheid. Verskeie tekste handel ook oor 'n beskrywing van hoe die "plek" sal lyk waar die regverdiges sal lewe na hulle opstanding (kyk 1 Henog 32:3; 2 Henog 8, 23:18, 30:1; 65:10; die Apokalips van Moses 37:5, 38:5, 40:1; 4 Esra 8:52; kyk Wright 2003:140-146 vir 'n bespreking van hierdie en nog ander ter sake tekste). Die gemeenskaplike oortuiging uit hierdie tekste is duidelik afleibaar: God het mag oor Sheol, en straf en beloning vind nie meer in hierdie lewe plaas nie, maar in die lewe na die opstanding.

Ook Qumran (vgl 1QH 11:11-12; 1QH 6:34) ${ }^{19}$ en die Fariseërs blyk dieselfde oortuiging te gehad het. Fariseïsme handel onder andere oor beloning en straf, en die opstanding is beskou as deel van beloning en straf. Paulus se opmerking in Handelinge $23: 6 b^{20}$ bevestig dat die Fariseërs, soos die eerste volgelinge van Jesus Christus, geglo het in 'n eskatologiese opstanding van die liggaam ${ }^{21}$. Hierdie is ook die gevolgtrekking van Wright (2003:190-200): op grond van veral tekste in die Mishna soos mAb 1:3 en mSot 9:15 (wat hy tussen 70 en 200 nC plaas, maar waarvan die wortels baie vroeër lê) oordeel hy dat die Fariseërs ook in 'n gemeenskaplike eskatologiese opstanding geglo het wat sal dien as 'n regverdiging van veral die martelare. Volgens Wright (1999:112) moet hierdie oortuiging van die Fariseërs ook verstaan word in terme van 'n wyer Farisese agenda wat hervorming, en self revolusie, ingesluit het. Opstanding vir hulle was "not simply the assurance of a newly embodied life after death" nie (Wright 1999:112), maar deel van 'n groter prentjie, te wete die oortuiging dat die God

\footnotetext{
${ }^{18}$ Volgens Filo dui die verwysings na die opstanding in Daniël 12:2 en Makkabeërs na die onsterflikheid van die siel, en nie na 'n eskatologiese liggaamlike opstanding nie (kyk Sanders 1976:25-44).

${ }^{19}$ Volgens Hengel (1981:199) is hierdie die enigste twee tekste uit die Qumran-literatuur wat dui op 'n moontlike verstaan van die opstanding as liggaamlik. Genoemde tekste is egter nie sonder probleme nie. Volgens Vermes (1981:187) kan hierdie tekste verstaan word as sou dit dui op 'n liggaamlike opstanding, maar dit kan ook allegories verstaan word, in die sin dat dit eerder dui op onsterflikheid as op liggaamlike opstanding. Josefus, in sy beskrywing van die Esseners, oordeel ook dat Qumran se oortuiging, wat betref lewe na die dood, eerder aansluit by die Hellenistiese beskouing van die onsterflikheid van die siel as 'n geloof in liggaamlike opstanding. Hippolitus, daarenteen, is van oortuiging dat Qumran geglo het dat "the flesh will also rise and be immortal, as the soul is already immortal" (kyk Riley 1995:19). Wright (2003:181-189) weer, is van oordeel dat die Esseners, soos die Fariseërs, geglo het dat die regverdiges 'n "siel" het wat die natuurlike dood sal oorleef, en dat hierdie "siele" deel van die algemene opstanding sal wees (kyk egter ook Wright 1999:112).

20 "Broers, ek is 'n Fariseër en kom uit 'n familie van Fariseërs. Dit is oor die verwagting dat die dooies weer sal opstaan dat ek verhoor word."

${ }^{21}$ Kyk Wright (2003:177-181), wat van oordeel is dat Josefus se verstaan van die opstanding in 'n baie groot mate met dié van die Fariseërs se verstaan daarvan ooreenkom.
} 
van Israel hulle huidige omstandighede van verdrukking sal verander in 'n hier-en-nou-wêreld van regverdigheid en vrede - 'n nuwe bedeling waarin die verdrukkers gestraf sal word en die regverdiges 'n nuwe wêreld sal kan geniet. "Resurrection, for the Pharisees, was thus part of their belief both in the goodness of the created, physical world and in the ultimate triumph of the justice of God" (Wright 1999:112).

Die Sadduseërs, daarenteen, het vasgehou aan die pre-eksiliese oortuiging oor lewe na die dood: die graf was einde van enige vrugbare lewe ${ }^{22}$ (kyk o a Segal 1997:102-108). Vir die Sadduseërs is beloning en straf deur die kultus bepaal: deur byvoorbeeld die offer op die Groot Versoendag word sondes weggeneem, en daarom is beloning of straf na die dood nie nodig nie (vgl Lev 16:30-34). Wright (2003:138) oordeel dat daar 'n verdere rede was waarom die Sadduseërs nie in die opstanding geglo het nie, naamlik dat geloof in die opstanding hulle gevestigde posisie as amptelike leiers van die Jode ernstig bedreig het: "People who believe that their god is about to make a new world, and that those who die in loyalty to him in the meantime will rise again to share gloriously in it, are far more likely to lose respect for a wealthy aristocracy than people who think that this life, this world and this age are the only ones there ever will be" (Wright 2003: 138) ${ }^{23}$.

\subsection{Lewe na die dood in die Grieks-Romeinse (Hellenistiese) wêreld} Indien die werke van Homeros gesien kan word as tipies van die denke oor lewe na die dood in die antieke Griekse wêreld, maak die antieke Grieke se denke geen voorsiening vir enige lewe na die dood nie (vgl // 24:549-551; 24:752; El 137-139). "In so far as the ancient non-Jewish world had a Bible, its Old Testament was Homer. And in so far as Homer has anything to say about resurrection, he is quite blunt: it doesn't happen" (Wright 2003:32). Daar

\footnotetext{
${ }^{22}$ Porter (1999:54-57), deur gebruik te maak van Josefus se beskouing van die Fariseërs, Sadduseërs en Esseners (Joodse Oorlog 2.119), oordeel dat die Fariseërs slegs geglo het in die onsterflikheid van die siel, en net vir hulle wat in hierdie lewe getrou aan die wet voor God gelewe het. Hulle oortuiging het dus, volgens Porter, nou aangesluit by die Grieke se verstaan van reïnkarnasie of metempsigose, en het nie die opstanding van die liggaam (al sou dit eskatologies wees) ingesluit nie. Wat die Sadduseërs betref, oordeel Porter dat Josefus, in lyn met Handelinge 23, korrek oordeel dat die Sadduseërs nie in enige lewe na die dood geglo het nie - nie eers wat betref die onsterflikheid van die siel nie. Wat die Esseners betref, oordeel Josefus dat hulle wel geglo het in die onsterflikheid van die siel. Porter se opmerkings is van belang om twee redes: 1) uit beskikbare bronne is dit nie moontlik om eenduidig af te lei watter sieninge die Fariseërs, Sadduseërs en Esseners gehad het wat betref dit wat met die mens na die dood gebeur nie, en 2) dat by hierdie groepe die gedagte beslis nie teenwoordig was dat die mens, na die dood, liggaamlik sou opstaan voor God se eskatologiese ingrype aan die einde van die tyd nie.

${ }^{23}$ In hierdie verband maak Wright (1999:112) ook die volgende opmerking: "The Sadducees, the ruling elite, denied a future life of any sort. This may be because those who believed strongly in the future life were more ready to risk death in seeking political or religious reform. One can well imagine that existing rulers would not wish to encourage such attitudes."
} 


\section{Die opstanding in die Jodedom}

is geen geneesmiddel vir die dood nie: nie opstanding of opwekking is moontlik nie (kyk o a Richardson 1985:50-66; Riley 1995:23-24; Porter 1999:68-70). Onsterflikheid, soos in die geval van die vroeë Jodedom, was geleë in die nalaat van 'n eerbare naam wat altyd onthou sou word.

Tog hou die afgestorwenes nie op om te bestaan nie, maar vertoef na die dood in Hades (vgl Od 11.51-56) in die vorm van 'n skaduwee (skiai), gees (psychai) of verskynings (eidola; kyk Wright 2003:39-43). Hierdie "vertoef" word deur Bremmer (1983:124) soos volg beskryf: "When we compare the soul of the living with the soul of the dead, we are struck by the negative way the souls of the dead are characterized. On the whole they are witless shades who lack precisely those qualities that make up an individual."

'n Verdere ontwikkeling in die Grieke se verstaan van lewe na die dood vind ons by Plato. Die Olimpiese gode (in die werke van Homeros), kan beskou word as materiële en antropomorfiese projeksies (vanuit die beperkte ervarings) van die mens. By Plato vind ons egter dat hierdie "immanente gode", as gevolg van 'n nuwe verstaan van die kosmos, verskuif word na die buitenste ruimte waar die sterre is ${ }^{24}$. Vanuit hierdie nuwe kosmologiese verstaan was die liggaam van die mens deel van die aardse en sigbare, en die siel deel van die onsigbare, nie-materiële buitenste ruim. "The soul came to be viewed as something originating in a sphere of being different from, and superior to, that of the body. The concept of the body too underwent change, from a positive vehicle of life ... to a distraction for and even the enemy of the soul" (Riley 1995:30). Volgens Plato is hierdie siel - anders as die liggaam, nie deel van die liggaam nie en vyand van die liggaam - onsterflik ${ }^{25}$. Vir Plato is die siel verder nie sonder individualiteit en identiteit nie (soos by Homeros), en daarom beweeg die siel deur 'n interim periode van beloning of straf ${ }^{26}$

\footnotetext{
${ }^{24}$ Hierdie lokalisering van die gode "by die sterre" dui op 'n duidelike ontwikkeling in terme van die verstaan van die kosmologie. Die tradisionele verstaan van die kosmos as "drie verdiepings" (Hades onder, dan 'n plat aarde wat op die oseane dryf, en bo die firmament, die hemele) is vervang deur 'n geosentriese verstaan van die kosmos: Hades was die binneste kern van die aarde, en rondom die aarde was die hemele, waar net (die) god(e) gewoon het. Die god(e) wat nou in die hemele gewoon het, kon nie in materiële en antropomorfiese terme beskryf word nie (Riley 1995:27).

${ }^{25}$ Plato verduidelik sy verstaan van die onsterflikheid van die siel soos volg: die skep van enige objek beweeg in terme van teenoorgesteldes. Die siel, as voorbeeld, beweeg dus van lewe na dood en dan van dood na lewe. Omdat die "idee" agter die siel van die mens lewe is, kan die siel van die mens dus in wese ook nie "sterf" nie (kyk Porter 1999:72).

${ }^{26}$ Porter (1999:69) oordeel dat die aspek van beloning of straf so vroeg as by Homeros aangetoon kan word, en nie eers by Plato voorkom nie. Porter grond sy standpunt op die inhoud van Od 11.51-83. Tekskritiese studies toon egter dat hierdie verse nie deel was van die oorspronklike teks nie, maar heel waarskynlik later ingevoeg is vanuit die klassieke periode toe hierdie oortuiging reeds bestaan het.
} 
voordat dit gereïnkarneer word tot "iets anders", in 'n volgende lewe. ${ }^{27}$. Die klassieke periode na Homeros toon dus 'n duidelike ontwikkeling wat betref die Grieke se verstaan van lewe na die dood: die siel is nie-materieel en onsterflik en sal geoordeel word. In die woorde van Porter (1999:73): "This implies continued existence for the soul after death."

Wright (2003:48-52) beskryf die verskil tussen Homeros en Plato ${ }^{28}$ (en by implikasie Sokrates) se verstaan van lewe na die dood soos volg: "Instead of the 'self' being the physical body, lying dead on the ground, while the 'soul' flies away to what at best is a half-life, now the 'self', the true person, is precisely the soul, while it is the corpse that is the ghost". Vir Plato is die siel nie-materieel, die aspek van die mens wat werklik saak maak. Die liggaam waarin die siel verkeer, is eintlik nie belangrik nie. Inteendeel. Die siel is verheug om van die liggaam (met die dood) ontslae te raak, en leef voort in Hades, wat eintlik baie beter is as die vorige lewe. Hades is daarom nie "a place of doom" nie, "but a place of delight" (Wright 2003:49). Dit is dan ook hoekom die siel nie vanaf Hades na die lewe terugkeer nie. Dit is baie beter daar as hier. In Hades self word die siel beoordeel: die wat regverdig verklaar word, gaan na die "Eiland van die Geseëndes", en die "slegte" siele gaan na Tartaros (kyk Wright 2003:50). Geen verwysing na opstanding van die liggaam kan egter by Plato aangetoon word nie.

Afgesien van Plato, vind ons min by ander Griekse filosowe in terme van verwysings na onsterflikheid en reïnkarnasie. Epikouros het die siel beskou as van dieselfde substansie as die liggaam, en daarom word die mens, as liggaam en siel, vernietig by die dood (Riley 1995:37-38). Ook die Stoïsisme het geen konsep van lewe na die dood nagehou nie, terwyl individue uit die Stoïsynse filosofie egter met mekaar verskil het oor die moontlikheid van die onsterflikheid van die siel (Riley 1995:39). Filo, op sy beurt weer, het ook nie iets soos 'n liggaamlike opstanding as 'n moontlikheid beskou nie, maar wel (in navolging van Plato) die gedagte van die onsterflikheid van die siel ondersteun (Goodenough 1946:85-108; Sandmel 1979:109-110; Wright 1999:112). Dieselfde geld vir die standpunt van Epiktetus: met die dood word die siel van die liggaam geskei. Die liggaam word weer stof, en die siel gaan na 'n plek wat anders as hierdie lewe is. Die dood is daarom niks anders as 'n proses van verandering nie, ' $n$ verandering na iets beters. Die dood hoef daarom nie gevrees te word nie. Ook Seneca se

\footnotetext{
${ }^{27}$ In terme van die antieke Griekse beskouing kan die begrip reïnkarnasie ook verstaan word as liggaamlike transformasie (metempsigose), wat beteken dat mens in 'n dier kan verander, en gode in mense (kyk Richardson 1985:61).

${ }^{28}$ Wright (2003:47-48) druk die verskil tussen Homeros en Plato se verstaan van lewe na die dood soos volg uit: "If Homer functioned as the Old Testament for the Hellenistic world ... its New Testament was unquestionably Plato."
} 


\section{Die opstanding in die Jodedom}

verstaan van die dood en lewe na die dood sluit nou hierby aan, en beide steun duidelik op die oortuiginge wat Sokrates in hierdie verband gehuldig het (kyk Wright 2003:53-55).

In die Grieks-Romeinse kultusse en misteriegodsdienste is geloof in die onsterflikheid van die siel ook afleibaar. Gemeenskaplik aan die kultusse van Isis (Demeter), Dionusos en Mithras vind ons die gedagte dat die siel na die onderwêreld (Hades) gaan na die dood, maar tog beter af is in terme van die antieke beskouing soos by Homeros. Ingewydes van hierdie kultusse sal almal, na die dood, deel word van 'n proses waar die siel deur fases van reiniging beweeg tot dat die siel "goddelikheid" ontvang ${ }^{29}$ (Riley 1995:34-36; Porter 1999:74-77).

Porter (1999:68-81) is egter ook van die oortuiging dat verskeie misteriegodsdienste in die Grieks-Romeinse wêreld hulle basis gevind het in mitologiese vertellings waarin daar nie alleen na die onsterflikheid van die siel verwys word nie, maar ook na die opstanding uit die dood.

There is very little evidence for a sustained Jewish development of the concept of resurrection, and certainly very little regarding a physical or bodily resurrection. The same cannot be said for what is found in Greek and Roman religion. In fact, there is a shockingly strong tradition of contemplation of the soul's destiny in the afterlife, along with examples of bodily resurrection.

(Porter 1999:68)

In hierdie verband verwys Porter (1999:75-76; kyk ook Strijdom 2003:1; Wright 2003:65) na byvoorbeeld die mite uit die Orfiese tradisie wat handel oor Dionusos-Zagreus wat opgewek word tot 'n nuwe lewe, die mite oor Isis wat Osiris uit die doderyk terugbring (Porter 1999:76; kyk ook Strijdom 2003:2), die mite waarin Apollonius 'n jong bruid uit die dood opwek (Lewe van Apollonius van Tiana 4.45; kyk Funk 1998:457), en mites in die Mithraskultus waaruit afgelei kan word dat hulle die oortuiging gehad het dat die liggaam, na fisiese dood, kan terugkeer om weer te lewe (kyk Porter 1999:76-77).

Verskeie ander mites vanuit die misteriegodsdienste verwys ook na opstanding en die hoop op ewige lewe (kyk Strijdom 2003:1-2). In die mite oor Orfeus en Euridike (Ovidius, Metamorfoses X:1-85, XI:1-66; kyk Funk 1998:463) keer Euridike byna terug uit die dood, in die Dionusos-kultus

\footnotetext{
${ }^{29}$ Cicero was byvoorbeeld ' $n$ ingewyde van die Isiskultus. Volgens Cicero sal hy, omdat hy 'n ingewyde van die kultus is, kan sterf met 'n "beter hoop". Hierdie "beter hoop", in die woorde van Plutargus, was om in Hades die voortdurende vooreg te hê om Isis te kan aanbid in die vorm van spel en dans (kyk Riley 1995:35-36).
} 
bestaan daar 'n mitologiese vertelling waar Dionusos sy moeder, Semele, in die doderyk gaan haal en terugbring tot lewe. In die Eleusiniese misteries bestaan daar 'n mite waar Persephone toegelaat word om vir 'n gedeelte van die jaar die doderyk te verlaat. In Ovidius se Metamorfoses keer Adonis ook vir 'n gedeelte van die jaar uit die doderyk terug. Die mite waarin die Griekse held Herakles vir Theseus en Alkestis uit die doderyk bevry, asook die mitologiese vertellings van Euripides (Hippolutos) waarin Asklepios vir Hippolutos uit die dood terugbring en Alkestis uit die dood terugkeer, is ook welbekend. Ook bekend is die mite waarin Sisuphos uit die dood terugkeer, asook die mite in Homeros se Odusseia waarin Odysseus/Aeneas uit die doderyk terugkeer.

Wright (2003:35) is egter van oordeel dat daar nie uit bogenoemde mitologiese vertellinge afgelei kan word dat daar in die Grieks-Romeinse wêreld die oortuiging bestaan het dat daar iets soos opstanding uit die dood was nie. Al wat Porter aantoon, volgens hom, is dat daar wel in die Griekse wêreld die geloof in 'n soort lewe na die dood bestaan het, dat hierdie oortuiging ontwikkel het in verskeie teorieë oor die aard van die lewe na die dood, en dat die mitologiese vertellings van die verskeie misteriegodsdienste voorbeelde van variante op dieselfde tema is. Die mite(s) oor Alkestis se terugkeer uit die dood is, alhoewel merkwaardig, nie genoeg gronde om te beweer dat die Grieke geglo het in opstanding na die dood nie. Soos Lasarus, sou sy weer sterf. Celsus, byvoorbeeld, het die Alkestis-mite verstaan vir wat dit was, 'n mite (kyk Wright 2003:35; 65-67).

Los van (buite) die wêreld van die poësie en filosofiese skole was dit egter die geval dat, soos in die Judaïsme, die kultus van die dooies baie lewend was onder die gewone Grieke. Afgestorwenes moes beklaag en begrawe word volgens bepaalde voorgeskrewe prosedures, die agtergeblewenes moes die graf versorg, en sekere voedsel moes na die graf geneem word en daar met die oorledende "gedeel" word. Daar is ook geglo dat lewe in Hades elemente van "normale" lewe (lewe voor die dood) bevat. Daarom is onder andere ook soms eetgerei, en selfs slawe of vroue saam met afgestorwenes begrawe (kyk Wright 2003:45). Verder is geglo dat afgestorwenes baie maklik deur ander afgestorwenes (en deur die wat nog lewe) herken sal kan word, aangesien die siel van die mens 'n "beeld" van die liggaam van die mens is. Ook liggaamsmerke wat iemand sou opdoen in die proses van sy/haar dood, was volgens die populêre Griekse beskouing sigbaar aan die siel ("beeld") na 'n persoon se dood. ${ }^{30}$

\footnotetext{
${ }^{30}$ Riley (1995:53-55) oordeel dat hierdie twee aspekte, te wete die siel as "beeld" van die liggaam na die dood (en dus herkenbaar) en die merke aan die "siel/"beeld" dit is wat agter die tradisies in Lukas en Johannes ten opsigte van Jesus se uitnodiging dat die dissipels aan Hom kan raak, lê.
} 


\section{Die opstanding in die Jodedom}

\subsection{Samevatting}

In sowel die Judaïsme as die Hellenisme was daar geen eenvormige verstaan van en oortuigings oor die lewe na die dood nie. Die Jodedom se verstaan oor lewe na die dood het 'n bepaalde ontwikkeling ondergaan: aanvanklik (in die pre-eksiliese tyd) is geoordeel dat die dood die einde van lewe was wat in Sheol geëindig het. Bestaan in Sheol was egter nie 'n nie-bestaan nie, wat duidelik blyk uit die kultus van die dooies wat veral populêr was onder die "gewone" Jode. Later, in die na-eksiliese tyd (op grond van die verstaan van God as alomteenwoordig en die sterf van martelare vir hulle godsdiens) ontwikkel daar 'n oortuiging dat daar eendag 'n (eskatologiese) algemene liggaamlike opstanding sal wees vir die regverdiges. Beloning en straf vind nie meer in hierdie lewe nie, maar in die lewe hierna plaas ${ }^{31}$. Sekere tekste skep ook die indruk dat 'n hoop op 'n individuele opstanding miskien voorgekom het (Ps 16:1-8; 22:9; 104:29; Job 33:15-30; kyk Kaplan 1988:19-20; Wright 2003:103-105). Behalwe dat daar ook verskille tussen die verskillende Joodse oortuigings aangetoon kan word, is dit ook nie uitgesluit dat verskeie Joodse groepe Hellenistiese sieninge in hierdie verband nagehou het nie. ${ }^{32}$

Wat lewe na die dood in die Grieks-Romeinse wêreld betref, is ook 'n duidelike ontwikkeling aangetoon, te wete vanaf die aanvaarding van die finaliteit van die dood (Homeros) tot 'n geloof in die onsterflikheid van die siel (Plato). Onsterflikheid, soos in die geval van die pre-eksiliese Jodedom, was geleë in die nalaat van 'n eerbare naam wat altyd onthou sou word. Soos die geval in die pre-eksiliese Jodedom, was die oortuiging dat die afgestorwenes in Hades nie 'n nie-bestaan gevoer het nie, maar in een of ander vorm voortgeleef het.

'n Verdere ontwikkeling in die Grieke se verstaan van lewe na die dood vind ons by Plato. Volgens Plato is hierdie siel - anders as die liggaam, nie deel van die liggaam nie en vyand van die liggaam - onsterflik. Die siel is nie sonder individualiteit en identiteit nie en beweeg deur 'n periode van beloning

\footnotetext{
${ }^{31}$ Vir ' $n$ meer volledige opsomming oor die ontwikkeling van die verskillende oortuigings oor lewe na die dood in die antieke Jodedom, kyk Wright (2003:200-206). Een aspek van hierdie opsomming deur Wright verdien verdere aandag: Wright beklemtoon baie sterk dat die geloof in 'n algemene eskatologiese opstanding nie verstaan moet word as 'n geloof in lewe na die dood nie, maar as 'n geloof in lewe na "die lewe na die dood". "'Resurrection' was life after 'life after death' ... resurrection was, more specifically, not the redefinition or redescription of death ... but the reversal or undoing or defeat of death" (Wright 2003:201).

${ }^{32}$ Wat betref die beïnvloeding van Joodse sieninge vanuit die Hellenisme maak Segal (1997:100, 102) die volgende baie interessante opmerking: "Resurrection (the remedy given by God to the Jews because of the cruelty and oppression of a foreign domination) was the preserve of the disenfranchised classes of people who could not abide foreign domination. By contrast, immortality of the soul was adopted mainly by classes of people who learned Greek culture and benefited from it." Ook Craffert (1999:56-57) toon aan dat sosiale omstandighede, klas en status 'n rol gespeel het in die nahou van 'n bepaalde oortuiging oor lewe na die dood.
} 
of straf voordat dit gereïnkarneer word tot "iets anders" in 'n volgende lewe. Die siel is dus verheug om van die liggaam (tydens die dood) ontslae te raak, en leef voort in Hades, wat eintlik baie beter is as die vorige lewe. Dit is dan ook hoekom die siel nie vanaf Hades na die lewe terugkeer nie.

Ook by die Griekse filosowe vind ons verskillende beskouings wat betref lewe na die dood. Epikouros het geoordeel dat daar geen lewe na die dood is nie (soos Homeros), so ook die Stoïsisme (alhoewel individue uit die Stoïsynse filosofie met mekaar verskil het oor die moontlikheid van die onsterflikheid van die siel). Filo, op sy beurt weer, het ook nie iets soos 'n liggaamlike opstanding as 'n moontlikheid beskou nie, maar wel (in navolging van Plato) die gedagte van die onsterflikheid van die siel ondersteun.

Dieselfde geld vir die standpunt van Epiktetus en Seneca (in navolging van Sokrates): na die dood gaan die siel na 'n plek wat anders as hierdie lewe is. Die dood hoef daarom nie gevrees te word nie.

In die Grieks-Romeinse kultusse en misteriegodsdienste is geloof in die onsterflikheid van die siel ook afleibaar, en daar is selfs sprake van 'n opstanding uit die dood. Daar bestaan egter sterk meningsverskil tussen verskeie geleerdes of die Grieke wel geglo het in opstanding na die dood. Ten slotte was die kultus van die dooies baie lewend onder die "gewone" Grieke.

\section{LEWE NA DIE DOOD IN DIE NUWE TESTAMENT}

Die Nuwe Testament verkondig dat Jesus begrawe is en liggaamlik uit die graf opgestaan het. Volgens Markus sterf Jesus aan 'n kruis terwyl 'n aantal vroue $^{33}$ op 'n afstand staan en kyk (Mk 15:33-42). Op versoek word die liggaam van Jesus deur Pilatus aan Josef van Arimatea oorhandig. Josef haal Jesus se liggaam van die kruis af, draai dit toe in 'n stuk linne wat hy gekoop het, lê Jesus neer in 'n graf wat in rots uitgekap was, en rol 'n klip voor die ingang van die graf (Mk 15:42-47). Soos in die geval van Jesus se kruisdood, vertel Markus dat die twee Marias ooggetuies van ook hierdie gebeure was. Op die eersvolgende Sondag, verhaal Markus, het die twee Marias en Salome die graf van Jesus vroegoggend besoek om die liggaam met reukolie te salf. By die graf vind hulle dat die klip weggerol is, en vind in die graf 'n jongman met wit klere aan wat aan die vroue vertel dat Jesus van Nasaret, wat gekruisig is, uit die dood opgewek is, en dat hulle vir die dissipels moet gaan vertel dat hierdie Jesus vir hulle in Galilea wag.

Twee aspekte van Markus se bogenoemde vertelling moet hier beklemtoon word. In die eerste plek beklemtoon Markus dat daar ooggetuies

\footnotetext{
${ }^{33}$ Volgens Markus 15:40-41 was hierdie vroue Maria Magdalena, Maria (die moeder van Klein-Jakobus en Joses), Salome, en nog baie ander wat Jesus reeds in Galilea begin volg het.
} 


\section{Die opstanding in die Jodedom}

teenwoordig was by Jesus se kruisiging (en dood) en begrafnis, asook van die feit dat die graf leeg was. Tweedens is die jongman by die graf se boodskap aan die vroue dat die een wat opgestaan het, Jesus van Nasaret is - die een wat gekruisig is en die een wat in die graf neergelê is. Die Jesus wat die dissipels in Galilea sal ontmoet, is dieselfde Jesus van Nasaret wat reeds in Markus 14:28 gesê het dat Hy hulle in Galilea sal ontmoet (vgl ook Mark 16:7). Dus, dit is dieselfde Jesus van Nasaret wat geleef het, wat hulle weer sal sien. Die Jesus wat van Nasaret af kom, die een wie hulle vanaf Galilea tot in Jerusalem gevolg het, is die Jesus wie hulle weer sal sien.

Indien ons sou aanvaar dat Matteus en Lukas van Markus gebruik gemaak het in die skryf van hulle onderskeie evangelies, wat het Matteus en Lukas van Markus gemaak? Literêr-krities beskou, is Matteus 27:45-56 feitlik 'n woordelikse weergawe van Markus 15:33-42: Jesus sterf terwyl 'n aantal vroue staan en $\mathrm{kyk}^{34}$, waarna Josef van Arimatea Jesus se liggaam (met toestemming van Pilatus) ontvang, en Jesus begrawe in 'n graf uit rots gekap terwyl die twee Marias toekyk. Ook Matteus 28:1-7 kom feitlik ooreen met Markus 16:1-7: die twee Marias het vroeg die Sondagoggend na die graf gegaan, en vind dat Jesus nie meer in die graf is nie. 'n Engel, wat op die klip sit wat voor die graf was, vertel aan hulle dat Jesus opgewek is, en dat hulle aan die dissipels moet gaan vertel dat Jesus vir hulle in Galilea wag. Markus en Matteus kom dus ooreen wat die volgende betref: Jesus sterf terwyl 'n aantal vroue staan en kyk, Josef van Arimatea rig 'n versoek tot Pilatus vir Jesus se liggaam, die versoek word toegestaan, Josef lê Jesus neer in 'n graf uit klip gekap terwyl die vroue toekyk, en die vroue vind die volgende oggend dat die graf leeg is.

Die klemtone van Markus 15:42-47 eggo dus duidelik in Matteus 27:4556 en 28:1-7: ooggetuies is teenwoordig by Jesus se kruisiging (en dood), sy begrafnis, en is getuies van die leë graf. Ook die boodskap wat by die graf aan hulle gekommunikeer word, is dieselfde: dié Jesus wat gekruisig is, is die een wat die dissipels in Galilea sal sien.

Watter verskille kan tussen Markus en Matteus aangetoon word? Drie verskille (byvoegings) in Matteus ten opsigte van Markus kan gelys word: (1) wanneer Jesus sterf, gaan die grafte van baie gelowiges oop, hulle gaan uit die grafte en na Jesus se opstanding gaan hulle Jerusalem binne (Matt 27:5152); (2) volgens Matteus 27:62-66 gee Pilatus die opdrag (op versoek van sommige Joodse leiers) dat Jesus se graf bewaak moet word sodat iemand nie sy liggaam steel en dan beweer dat Jesus opgestaan het nie; en (3) volgens Matteus 28:2-4 het die vroue die graf toe gevind, 'n aardbewing het

\footnotetext{
${ }^{34}$ Volgens Matteus 27:55-56 was onder hierdie vroue Maria Magdalena, Maria (die moeder van Jakobus en Joses), en die moeder van die seuns van Sebedeus.
} 
plaasgevind, 'n engel het van die hemel af gekom en die klip voor die graf weggerol en daarop gaan sit.

Lukas se weergawe van Jesus se kruisiging en opstanding kom in wese ook ooreen met Markus (en Matteus) se weergawes daarvan. Volgens Lukas 23:44-56 sterf Jesus terwyl al sy vriende en die vroue wat Hom van Galilea af gevolg het, as ooggetuies teenwoordig is. Josef van Arimatea vra Jesus se liggaam van Pilatus, en begrawe Jesus (in linne toegedraai) in 'n rotsgraf, ook met die vroue as ooggetuies. Op die Sondag het die vroue die graf besoek, die klip weggerol gevind en die graf leeg. Twee manne (in blink klere) het toe aan hulle verskyn, en aan hulle vertel dat Jesus (die een wat met hulle in Galilea gepraat het, vgl Luk 24:6-7), opgestaan het.

Die twee klemtone in Markus en Matteus se vertellinge oor Jesus se dood en opstanding waarna hierbo verwys is, vind ons dus ook in Lukas 23:44-24:7: eerstens is ooggetuies teenwoordig by Jesus se kruisiging (en dood), sy begrafnis, en is getuies van die leë graf. Tweedens is die boodskap wat by die graf aan hulle gekommunikeer word, dieselfde as by Markus en Matteus: die Jesus wat gekruisig is, is dieselfde Jesus van Nasaret wat hulle in Galilea leer ken het. Dit is hierdie Jesus wat die dissipels in Galilea sal sien.

Uit die drie Sinoptiese Evangelies kan ons dus die volgende "basisvertelling" aflei: Jesus sterf in die teenwoordigheid van die vroue as getuies, Josef van Arimatea verkry sy liggaam vanaf Pilatus, en begrawe Jesus (ook met die vroue as getuies). Op die Sondag kom die vroue na die graf, en is ooggetuies van die leë graf. In al drie gevalle is die boodskap wat hulle by die leë graf ontvang dieselfde: die Jesus wat hulle in Galilea ontmoet en leer ken het, die Jesus wat gekruisig is, is die Jesus wat opgestaan het en wie die dissipels in Galilea sal ontmoet.

Wanneer die vertellinge oor die na-opstandingverskynings van Jesus in die Evangelies (Matt 28:8-10; 28:16-20; Luk 24:13-35; 24:36-49; Joh 20:11$18 ; 20: 19-25 ; 20: 26-31 ; 21: 1-19)$ teen die agtergrond van bogenoemde "basis-vertelling", en twee aangeduide klemtone gelees word, kan die volgende afgelei word: in Matteus 28:8-10 herken die vroue Jesus dadelik. Met ander woorde, hulle het onmiddellik geweet dat die een wat voor hulle staan, die Jesus was wat hulle in Galilea leer ken het, en van wie se dood en begrafnis hulle ooggetuies was. Uit Matteus 28:16-20 kan dieselfde afleiding gemaak word: toe die dissipels Jesus sien, het hulle Hom aanbid (hoewel nie almal nie). Hulle het Hom dus erken as die Jesus wat hulle in Galilea begin volg het. Dat die Jesus wat nou voor hulle staan, dieselfde Jesus is wat hulle in Galilea ontmoet het, word verder deur Matteus 28:20 beklemtoon: wat hulle moet gaan verkondig is dit wat hulle by Jesus (van Nasaret) gehoor het en wat Hy hulle (voor sy dood) geleer het. Gelees vanuit hierdie hoek, is dit wat 


\section{Die opstanding in die Jodedom}

Matteus onder andere met laasgenoemde twee vertellings wil kommunikeer, duidelik: die Jesus wat nou aan die vroue en die dissipels verskyn, is dieselfde Jesus wat hulle geken en gevolg het voor sy kruisdood.

Kan dieselfde afleiding ten opsigte van Lukas en Johannes se vertellings oor die na-opstandingverskynings van Jesus gemaak word? In Lukas 24:13-35, die vertelling oor die Emmausgangers, word Jesus beskryf op dieselfde wyse as op die voor-Pase vlak van die vertelling: Hy loop saam met die twee Emmausgangers (Kleopas en 'n vriend) op pad na Emmaus en voer met hulle 'n gesprek. Die inhoud van die gesprek verwys spesifiek na Jesus van Nasaret as die een van "wat magtig was in woord en daad", wat gearresteer, veroordeel en gekruisig is, en van wie vertel word dat sy graf leeg is. Soos Hy dikwels op 'n voor-Pase vlak gedoen het, leer Jesus hulle. Wanneer hulle dan aan tafel is en Jesus die brood breek, erken hulle Jesus. Wat is die gronde vir hierdie erkenning? Die feit dat Jesus, saam met sy vroeëre uitleg van die Skrifte, die brood breek soos Hy gepredik en die brood voor sy dood en opstanding gebreek het. Die Jesus "hier" word dus as Jesus erken op grond van die Jesus "daar". Dieselfde gevolgtrekking kan gemaak word ten opsigte van Lukas 24:36-49. Wanneer Jesus aan die dissipels verskyn, oordeel hulle aanvanklik dat hulle 'n gees sien. Jesus wys hulle egter op sy liggaamlikheid, en vra ook iets om te eet. Jesus verwys ook na "die woorde wat Ek vir julle gesê het toe Ek nog by julle was" (Luk 24:44). Dus, die Jesus hier nou by hulle is dieselfde Jesus wie hulle gevolg het sedert Galilea.

Ook vanuit die Johannesevangelie kan dieselfde afleiding gemaak word, te wete dat die Jesus wat na die opstanding verskyn, dieselfde Jesus as Jesus van Nasaret is. Volgens Johannes 20:11-18 erken Maria Jesus wanneer Hy haar op haar naam noem. Maria erken Jesus dus op grond van die verhouding wat tussen hulle op die voor-Pase vlak van die vertelling bestaan het. In Johannes 20:19-25 erken die dissipels Jesus wanneer Hy sy hande en sy vir hulle toon, dit wil sê, dat Hy die een is wat gekruisig is. Ook was hulle baie bly om die Here te sien. Kan hieruit afgelei word dat hulle blydskap te make het met die feit dat hulle Jesus weer sien, Hy weer by hulle is, soos dikwels in die verlede?

In Johannes 20:26-31 erken (op grond van sien) Tomas Jesus ook aan die merke aan sy hande en sy sy. Tomas erken die opgestane Jesus dus as die een wat gekruisig is. Uit Johannes 21:1-19 kan dieselfde afleiding gemaak word: die opgestane Jesus word as Jesus van Nasaret erken op grond 'n gebeure wat op die voor-Pase vlak van die vertelling gebeur het, en nou hier herhaal word ('n wonderbaarlike visvangs). Na hierdie visvangs nooi Jesus hulle uit om te eet en, soos in die verlede, eet hulle weer saam. Dus: deur 
herinnering het hulle geweet dat dit dieselfde Jesus is wat nou by hulle is as die Jesus by wie hulle altyd was.

Sonder om enigsins die verskille in die Evangelies oor die kruisiging, dood, begrafnis, opstanding en na-opstandingverskynings van Jesus te ontken, kan die "saak" wat die Evangelies in hierdie verband wil kommunikeer, soos volg saamgevat word:

- $\quad$ Jesus is gekruisig (met ten minste sekere vroue as getuienisse daarvan), is begrawe deur Josef van Arimatea (met vroue as getuienisse daarvan), Jesus het in die liggaam opgestaan (vroue vind die graf telkens eerste leeg), en na sy opstanding verskyn Jesus aan vroue en aan die dissipels.

- Jesus verskyn aan van hierdie getuienisse en aan die dissipels na sy opstanding. Tydens hierdie ontmoetings erken hulle die opgestane Jesus as die Jesus wat hulle voor die opstanding leer ken het. Dit is dus dieselfde Jesus wat nou by hulle is as die Jesus wat hulle in Galilea leer ken, vandaar gevolg het tot in Jerusalem waar Hy gekruisig is, begrawe is en opgestaan het.

In aansluiting by bogenoemde gevolgtrekking is die volgende opmerking van Niebuhr van belang:

The outstanding feature of these passages is not their emphasis on the corporeal as such, but on identification and recognition, and hence on the flesh insofar as it is the medium of recognition. In the narratives, Jesus is remembered as appearing and offering food as he offered it at the last supper, and as showing the marks of his death on the cross. The other details, with the exception of eating food himself, are connected with these essential features of Jesus' identity in the memory of the disciples.

(Niebuhr 1957:173)

Gesien teen die agtergrond van die Jodedom se verwagtings oor die opstanding (kyk weer Afd 2.1), was dit wat in Jesus gebeur het, beslis iets nuut. Die na-eksiliese Jodedom het 'n algemene opstanding verwag, 'n opstanding waartydens al die martelare as regverdiges opgewek sal word, Israel herstel sal word, en 'n nuwe era sal aanbreek, 'n era wat gekenmerk sal wees deur vrede en geregtigheid. Wright (2003:205) tipeer hierdie verwagting ten opsigte van die algemene opstanding soos volg: 


\section{Die opstanding in die Jodedom}

[R]esurrection, in the world of second-Temple Judaism, was about the restoration of Israel, on the one hand and the newly embodied life of all YHWH's people on the other, with close connections between the two; and that it was thought of as the great event that YHWH would accomplish at the very end "of the present age", the event which would constitute the "age to come".

(Wright 2003:205; sy beklemtoning)

Niemand het egter verwag dat enige individu voor die aanbreek van hierdie algemene opstanding sou opstaan nie. "It was never envisaged that one person might receive 'resurrection' while the rest of history continued unchecked" (Wright 1999:114; sy beklemtoning) ${ }^{35}$. Jesus se kruisiging deur onder die regering van die Romeine het vir die Jood beteken dat die ou bedeling nog hier was. Jesus se opstanding het dit alles verander. Jesus het nie alleen opgestaan nie, maar die nuwe bedeling het aangebreek, hoe paradoksaal ook al. Die ou bedeling was nog hier, maar die nuwe bedeling was ook hier, 'n bedeling waarvan die opgestane Heer deel was (Wright 1999:116-117).

\section{SLOTOPMERKINGS}

Bogenoemde gevolgtrekking is gebaseer op 'n bepaalde verstaan van die opstandingvertellings en na-opstandingvertellings in die Evangelies. Kan hierdie vertellings egter as histories betroubaar beskou word? Is dit wat die Evangelies oor die dood, opstanding en na-opstandingverskynings van Jesus berig, nie eerder teologie as geskiedenis nie? Ons het byvoorbeeld geen ooggetuieverslag oor die opstanding van Jesus nie. Moet die vertellings in die Evangelies oor Jesus se opstanding en verskynings na sy opstanding nie eerder as gemeenteteologie gesien word nie? Of was ervaringe van hulle wat die opgestane Here gesien het, nie maar net hallusinasies nie?

Wat van die verskeie misteriegodsdienste in die Grieks-Romeinse wêreld wat hulle basis gevind het in mitologiese vertellings waarin daar nie alleen na die onsterflikheid van die siel verwys word nie, maar ook na die opstanding uit die dood en die hoop op ewige lewe (kyk weer Afd 2.2)? Volgens hierdie mites sou God binne die drieverdieping-kosmos ingryp om mense te verlos deur die goddelike genetiese saad aan 'n aardse maagd oor te dra (bv Zeus aan Semele), wat dan 'n held in die wêreld laat bring (bv

\footnotetext{
${ }^{35}$ In hierdie verband maak Segal (1997:111) die volgende opmerking: "These stories (die vertellings in die Evangelies oor Jesus se opstanding - EvE) clearly say that the resurrection was corporeal and very real. It was unique; it was bodily; it was apocalyptic; and it was God's merciful response to Jesus' willing martyrdom. The result is that Jesus is the first of those to rise bodily from the dead at the end of time."
} 
Dionusos), wat dan groot dade en wonderwerke doen, sterf, afdaal doderyk toe (bv Odusseus), opstaan en opvaar hemel toe (bv Herakles). Partykeer verskyn hy ook aan mense en ontstaan daar 'n kultus rondom hom. Van Mithras is byvoorbeeld geglo dat hy sal terugkom om sy vyande te oordeel en te straf. Is die parallelle met Jesus darem nie te ooglopend nie? Met ander woorde, was Jesus nie maar net 'n Joodse rabbi wat ná sy kruisdood binne die raamwerk van die Griekse heldepatroon geïnterpreteer is nie?

Hierdie, en verskeie ander vrae verdien ons aandag, en sal in 'n volgende artikel aan die orde gestel word (kyk Van Eck 2004). In die besonder sal aandag gegee word aan enkele fasette van die debat oor die opstanding van Jesus wat in die verlede gevoer is, en in die hede gevoer word. Aandag sal gegee word aan die standpunte van drie prominente deelnemers aan die huidige debat oor die opstanding, te wete William Lane Craig, Gerd Lüdemann en John Dominic Crossan. Die standpunte oor die opstanding van die genoemde Nuwe-Testamentici sal gebruik word as vertrekpunt om twee sake wat van belang is in die ondersoek na die opstanding van Jesus aan die orde te stel: die verhouding tussen vooronderstellings en resultate (in die ondersoek na die opstanding van Jesus Christus), en die aard van die tekste van die Nuwe Testament as geskiedenis en teologie. Ten slotte sal 'n eie verstaan van die opstanding, en na-opstandingverskynings van Jesus, aangebied word.

\section{Literatuurverwysings}

Borg, M J \& Wright, N T 1999. The meaning of Jesus: Two visions. New York, NY: HarperCollins.

Bremmer, J 1983. The early Greek concept of the soul. Princeton, NJ: Princeton University Press.

Charlesworth, J H (ed) 1983. The Old Testament Pseudepigrapha, Vol 1. New York, NY: Doubleday.

Craffert, P F 1999. Meeting the living among the dead: Perspectives on burials, tombs and the afterlife. Pretoria: Biblia Publishers.

Crossan, J D 2003. Resurrection of Jesus in its Jewish context. Neotestamentica 37, 29-57.

Day, J 1996. The development of belief in life after death in ancient Israel, in Barton, $\mathrm{J}$ en Reimer, D J (eds), After the exile: Essays in honor of Rex mason, 231257. Macon: Mercer.

Eichrodt, W 1967. Theology of the Old Testament. Philadelphia, PA: Westminster Press.

Funk, R W and the Jesus Seminar 1998. The acts of Jesus: The search for the authentic deeds of Jesus. New York, NY: HarperCollins.

Goodenough, E R 1946. Philo on immortality. HTR 39, 85-108.

Gowen, D 1980. Eschatology in the Old Testament. Philadelphia, PA: Fortress Press. Hengel, M 1981. Judaism and Hellenism. Philadelphia, PA: Fortress Press. 


\section{Die opstanding in die Jodedom}

Jacob, E 1958. The theology of the Old Testament. London: Hodder \& Stoughton. Kaplan, B S 1988. The concept of resurrection in Judaism and Christianity. MA Dissertation, University of South Africa.

Kaufmann, Y 1960. The religion of Israel. Chicago, IL: University of Chicago Press.

Niebuhr, R R 1957. Resurrection and historical reason: A study of theological method. New York, NY: Charles Scribner's Sons.

Porter, S E 1999. Resurrection, the Greeks and the New Testament, in Porter et al (eds) 1999:52-81.

Porter, S E, Hayes, M A \& Tombs, D (eds) 1999. Resurrection. Sheffield: Sheffield Academic Press (Journal for the study of the New Testament Supplement Series 186.)

Richardson, N J 1985. Early Greek views about life after death, in Easterling, P E \& Muir, J (eds), Greek religion and society, 50-66. Cambridge, UK: Cambridge University Press.

Riley, G J 1995. Resurrection reconsidered: Thomas and John in controversy. Minneapolis, MN: Fortress Press.

Ringgren, H 1966. Israelite religion. Philadelphia, PA: Fortress Press.

Russell, D S 1964. The method and message of Jewish apocalyptic. London, UK: SCM.

Sanders, E P 1976. The covenant as a soteriological category and the nature of salvation in Palestinian and Hellenistic Judaism, in Hammerton-Kelly, R \& Scroggs, R (eds), Jews, Greeks and Christians: Religious cultures in late antiquity, 25-44. Leiden: E J Brill.

Sandmel, S 1979: Philo of Alexandria: An introduction. Oxford, UK: Oxford University Press.

Segal, A F 1997. Life after death: The social sources, in Davis et al 1997:90-125.

Strijdom, J 2003. Om terug te keer uit die dood, om ewig te lewe na die dood:

Grieks-Romeinse parallelle vir die vroeg-Christelike mites van die opstanding uit die dood en die ewige lewe. Ongepubliseerde voordrag gelewer tydens 'n byeenkoms van die NT-Gespreksgroep, Universiteit van Pretoria, op 21 Februarie 2003.

Van Eck, E 2004. Die opstanding van Jesus Christus as historiese gebeure. HTS 60(3).

Vermes, G 1981. The Dead Sea Scrolls: Qumran in perspective. Philadelphia, PA: Fortress Press.

Wolf, H 1985. Interpreting Isaiah: The suffering and glory of the Messiah. Michigan, Ml: Academic Books.

Wright, N T 1999. The transformation reality of the bodily resurrection, in Borg \& Wright 1999:111-127.

Wright, N T 2003. Christian origins and the people of God, Vol 3: The resurrection of the Son of God. Minneapolis, MN: Fortress Press. 